\title{
'N OPINIE OOR DIE BEHAVIOURISTIESE SIENING VERSUS DIE FENOMENOLOGIE AS GRONDSLAG VIR EFFEKTIEWE OPLEIDING IN WEERMAGSVERBAND
}

\author{
KAPT (MEV) H. HARMSE*
}

\author{
(Quot homines tot senteniae)
}

\begin{abstract}
This article consists of a brief discussion on the merits of the phenomenological school of thought in comparison with the better known behaviouristical school, in creating a firm base for effective training methods within the Defence Force.
\end{abstract}

\section{Inleiding}

Geesteswetenskaplikes glo reeds vir dekades dat die moontlikheid tot effektiewe ontwikkeling van menslike potensiaal opgesluit lê in 'n grondige kennis van die mens, ook as psigiese wese.

Aangesien daar in weermagsverband daagliks bemoeienis gemaak word met die opleiding van groot en uiteenlopende groepe mense, is dit te verstane dat verskeie sielkundige denkrigtings en antropologiese sienswyses onder oë geneem sal word in die voortdurende soeke na 'n grondslag of grondslae vir die mees effektiewe opleidingsmetodes. Met die mees effektiewe opleidingsmetodes in die hand, word dan optimale ontwikkeling of verwerkliking van beskikbare mensemateriaal geïmpliseer.

In hierdie studie sal kortliks aandag gegee word aan die sienings ten opsigte van leer vanuit die meer bekende behaviouristiese denkrigting in vergelyking met die fenomenologie, wat tot nog toe min aandag ontvang het as potensiële grondslag vir opleiding in weermagsverband.

\section{Begripsverheldering}

\section{Behaviourisme}

Hoewel dit belangrik is om te besef dat daar binne die behaviouristiese skool redelik wyduiteenlopende gedagtes deur die jare ontstaan het, kan 'n redelike eenvormige siening ten opsigte van leer as menslike verskynsel geïdentifiseer word.

Opsommend word leer gesien as 'n relatiefpermanente gedragsverandering wat ontstaan deur volgehoue inoefening.

Baie eenvoudig verduidelik, sien die behaviouristiese denkrigting die mens as 'n blote verlengstuk van die dier. Die mens is dus voorspelbaar en leer op die stimulus-respons beginsel.

Daar sal nie hier op die verskillende leerprosesse wat onderskei word, ingegaan word nie. Daar word volstaan met die noem van enkele prosesse om die stimulus-responsgedagte net toe te lig, byvoorbeeld die probeer-en-tref metode, leer deur ontkoming aan of vermyding van die onaangename, leer deur sosiale ervaring en ook verskeie vorme van kondisionering. In al hierdie gevalle word 'n stimulus gegee en die mens gelei tot die gewenste reaksie.

Die hele gedagterigting is gebou op verhoudings van elemente tot mekaar en assosiasie en verwantskappe tussen elemente wat deur middel van herhaling en inoefening bevestig, bekragtig en versterk word.

Eksperimente ter stawing van die bogenoemde teorieë is deurgaans op diere uitgevoer. Die reaksie is dan op die mens oorgedra as die waarskynlikste reaksie. (Vergelyk in hierdie verband die eksperimente van Pavlov, Thorndike, Skinner, Tolmann en Hull.)

\section{Fenomenologie}

Die fenomenologie is 'n essensie-openbarende denkrigting. Dit impliseer ' $n$ denkende soektog na dit wat 'n besondere verskynsel of werklikheid maak juis dit wat dit is en nie iets anders nie.

In die fenomenologiese antropologie gaan dit om die mens as unieke wese; as totaliteit in die werklikheid wat onlosmaaklik aan sy omwêreld verbonde is en voortdurend deur sy omgewing beïnvloed word.

Die menslike leergebeure moet dus ook uniek wees en kan nie van diere-eksperimente afgelei word nie. Verder kan leer as menslike verskynsel nooit geïsoleerd van die menslike leefwêreld 
gesien word nie, omdat dit die verlengstuk van die basies-menslike opvoedingsgebeure is. Dit beteken dat 'n mens se houding ten opsigte van leer 'n direkte verband het met sy opvoeding en vroeëre leerervaringe.

In die fenomenologiese denkrigting vind ons miskien die skerpste kontras met die behaviourisme daarin dat die mens deur eersgenoemde gesien word as wilswese wat (as gevolg van sy moontlikheid tot self wil) nie bloot 'n verlengstuk van die dier is nie, maar soos die Bybel hom sien: weinig minder as 'n goddelike wese geskape is. Op grond van sy wil is die mens (anders as die dier) nie uitgelewer aan sy omstandighede nie; hy behou die vermoë tot eie keuse.

Die mens kan voortdurend vir of teen sy omstandighede kies, wat meebring dat hy nie noodwendig sal reageer soos verwag word nie. Hy kan dus weier om te leer of weier om 'n spesifieke mening te huldig en sodoende dus buite verband met die behaviouristiese kondisioneringsbeginsel optree.

\section{Bespreking}

Wanneer nou na opleiding synde onderrig en leer gekyk word teen die agtergrond van die voorafgaande, word die volgende vir die leser duidelik:

\section{Behaviourisme}

Opleiding (in die lig van die breë behaviouristiese siening) vereis bloot taakgerigte leerplanne met die verwagting van voorafbepaalde reaksies by die student, ongeag enige eksterne of selfs interne faktore wat 'n invloed mag hê op die individu.

Mislukking om na verwagting te reageer op 'n gegewe stimulus, word òf bloot toegeskryf aan 'n onvermoë by die student, òf aan 'n gebrekkige stimulus, assosiasie en/of inoefening. By die laasgenoemde aspekte word die proses net herhaal met 'n verskerpte stimulus, assosiasies en inoefening, sonder inagneming van die individu as wilswyse as unieke totaliteit in 'n eie unieke omwêreld met die invloede wat daarmee gepaard gaan.

Vanuit die behaviouristiese oogpunt word klem gelê op tegnieke en die tempo waarteen 'n spesifieke tegniek 'n indruk maak en die nodige gedragsverandering by die mens laat plaasvind

\section{Fenomenologie}

Die fenomenologie glo, in teenstelling hiermee, dat 'n grondige kennis van die mens in sy wêreld gemaak moet word. Die instrukteur moet (buiten sy tegniese hulpmiddele, metodes en leerplanne) bewus wees van sy studente as medemense wat elk op hul eie manier voortdurend dialoog voer met hul omwêreld.

Die fenomenologie wys daarop dat die mens oop staan vir sy wêreld, maar deur wil en keuse self besluit hoe hy gaan reageer. Hy kàn dus nie in 'n vorm gegiet word nie.

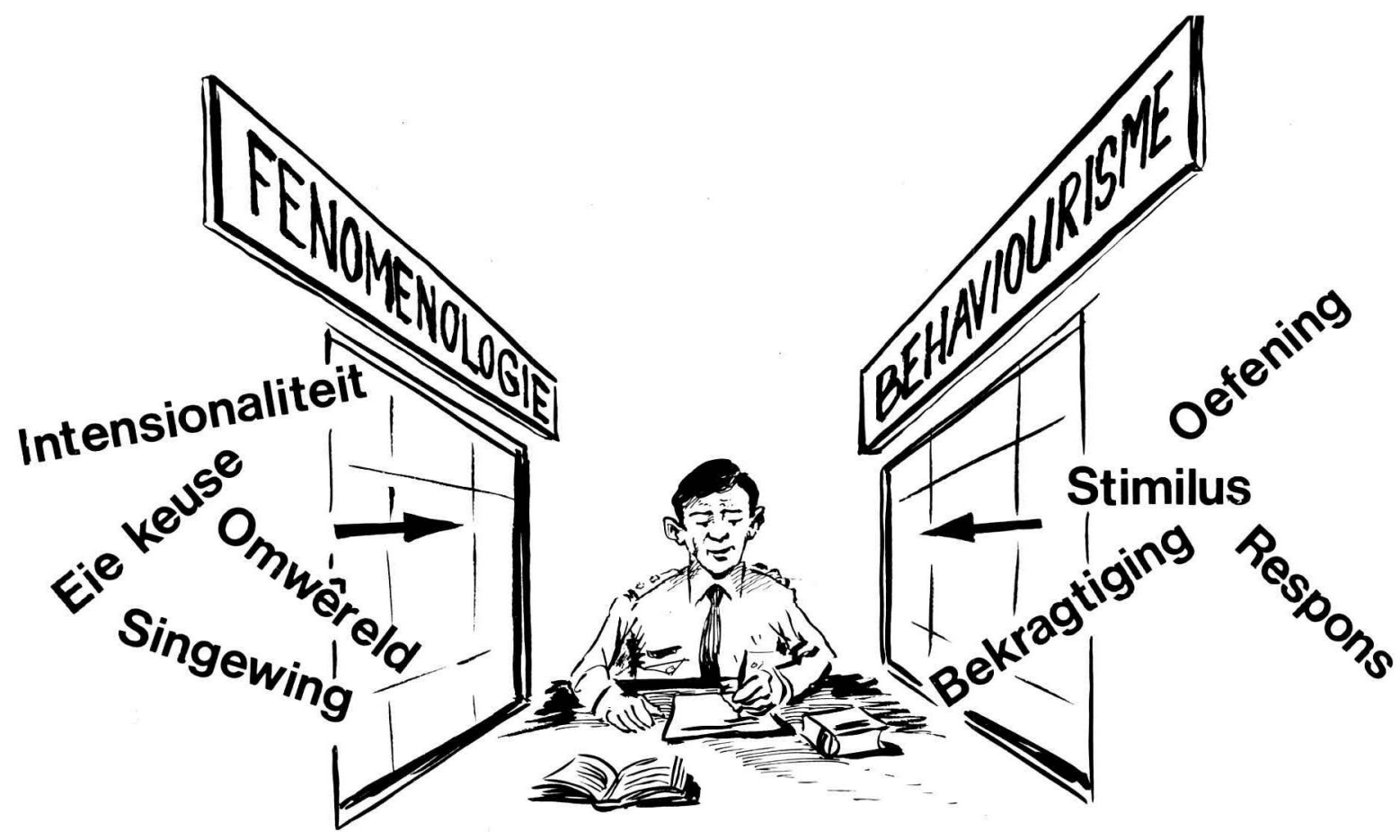




\section{Die rol van die instrukteur in leer}

Vir die taakgerigte behaviouris is dit net die stimulus, die respons en die student wat van belang is. Die fenomenologie bring die instrukteur as deel van die student se omwêreld akuut na vore. Sy voorbeeld, sy houding, sy gesindheid en gemotiveerdheid ten opsigte van die leerstof, sy mens-as-medemens wees in die student se teenwoordigheid, het 'n geweldige effek op die student se wil om te leer.

\section{Sin en betekenisgewing deur die stu- dent}

Die behaviouris aanvaar dat die mens noodwendig sal leer in teenwoordigheid van die gegewe stimulus en geleentheid tot inoefening van die bepaalde verwagte reaksie.

Fenomenologie sien die mens as eksistensiële, intensionele wese. Anders gestel: die mens tree uit, tree toe (eksisteer) tot sy omwêreld. Hy rig hom op en raak betrokke by - sy omwêreld. Hierdie intensionele gerigtheid impliseer betekenisgewing en sinbelewing.

Wanneer die student in sy gerigtheid tot sy wêreld negatief betekenis gee en geen sin beleef nie, onttrek hy sy wil tot leer. Alleen deur outentieke singewing aan die leermateriaal as nuttig vir hom, sal die student weer gebring kan word tot die wil om te leer.

Opsommend gaan dit dus hier om die motivering van die student tot sinvolle betekenisgewing, sinbelewing en wil.

Wanneer in diepte op die fenomenologiese antroplogie ingegaan word, word verdere menslike kategorieë soos vertroue, hoop, ervaring, belewing en ken in detail bespreek. Aangesien elk van hierdie 'n artikel op sigself regverdig, sal hier nie daarop ingegaan word nie.

Die skryfster glo dat die voorafgaande gedagtes genoeg is om die leser van die hieropvolgende samevattende gevolgtrekking te oortuig.

\section{Samevattende gevolgtrekking}

Aangesien ' $n$ baie groot hoeveelheid van die opleiding in weermagsverband die aanleer van praktiese vaardighede insluit, is dit logies dat die taakgerigte kondisioneringsgedagte baie aftrek sou kry. Wat egter vir baie lank misgekyk is, is die mens wat as soldaat opgelei moes word om die taak te verrig. Mislukkings op operasionele gebied is telkens toegeskryf aan swak opleidingsmetodes en -tegnieke, swak leerplanne, te min tyd vir inoefening, ensovoorts.

Dit is maar in die jongste tyd dat die besef begin posvat dat 'n mens tydelik deur vrees vir byvoorbeeld dissiplinêre maatreëls oënskynlik gekondisioneer word en na wense reageer. Wanneer dit egter op die man af kom, is die gebrek aan vertroue in sy leier/instrukteur, sowel as 'n gebrek aan motivering, sin, betekenisgewing, hoop en ook wil die deurslaggewende faktore.

Dit is dus sinvol dat die waardevolle tegnieke en metodes wat deur die jare ingespan is (met slegs die behaviouristiese siening as agtergrond) vandag sterk gekleur sal word deur die fenomenologiese mensbeskouing. Daar sal nie slegs gepoog word om die hand vaardig te kry nie, maar ook om die gees gewillig te kry.

Ten spyte van die skerp kontras tussen die twee het die behaviourisme en fenomenologie in weermagsopleidingsverband nogtans na die skryfster se mening veel vir mekaar te sê. Indien te veel klem op die taak gelê word, word die mens wat daardie taak moet verrig die struikelblok. Sou daar egter net aandag aan die mens gegee word, sou lewensbelangrike dissipline en taakgerigtheid in die slag bly. Effektiewe opleiding in weermagsverband impliseer dus 'n gebalanseerde aandagverhouding tussen die taak en die mens wat die taak moet verrig.

Anders gestel: 'n grondslag wat nie ekstreem een denkrigting aanhang nie, maar die waardevolle uit vele denkrigtings saamtrek, behoort tot 'n gebalanseerde en effektiewe eindresultaat te lei.

\footnotetext{
* Kaptein Henriette Harmse (BA, HNOD, B Ed, M Ed) was vana Januarie 1977 tot Desember 1979 verbonde aan Afdeling Personeel (Direktoraat Beroepsontwikkeling) waar sy onder andere die multimediasleepwa ontwerp het en waardevolle werk ten opsigte van die ontwikkeling van mediasentra en die mediasentrumkoördineerderskursus gedoen het. Vanaf Januarie 1980 was sy verbonde aan Kommandement OVS. Sy het aan die einde van Februarie 1981 die diens van die SAW verlaat.
}

\section{Bronnelys}

Geldard, F. A.: Fundamentals of Psychology, 1963. USA

Landman en Roos: Fundamentele pedagogiek en die opvoedingswerklikheid, Durban, 1973.

MacKenzie, B. D.: Behaviourism and the Limits of Scientific Method, London, 1977.

Strauss, E.: Phenomenological Psychology: Selected Papers, London, 1966

Thinés, G.: Phenomenology and the science of Behaviour, London, 1977.

Van der Stoep, F.: Didaktiese Grondvorme, Pretoria 1969.

B Ed aantekeninge: UP, 1974 